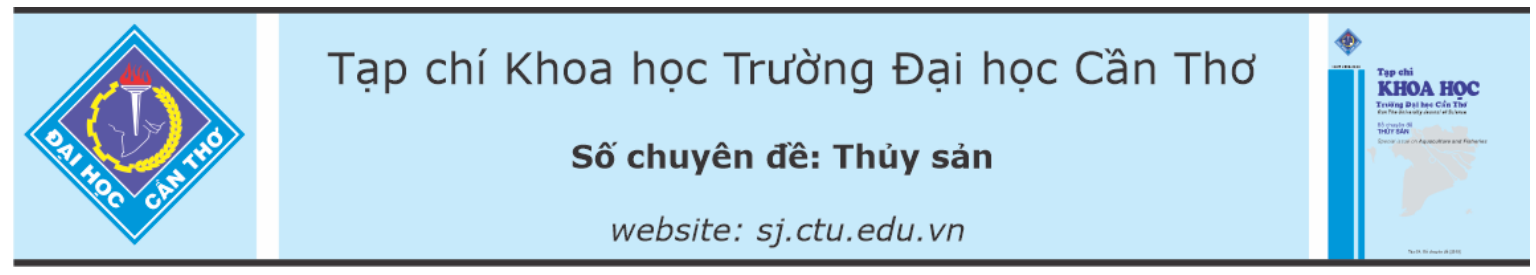

DOI:10.22144/ctu.jvn.2021.076

\title{
ẢNH HƯỞNG CHU KỲ BỔ SUNG CHÂT CHIÊT LÁ CÁCH (Premna serratifolia L.) LÊN ĐÁP ÚNG MIỄN DỊCH VÀ KHẢ NĂNG KHÁNG BỆNH CỦA CÁ TRA (Pangasianodon hypophthalmus)
}

Bùi Thị Bích Hằng* và Trần Thị Tuyết Hoa

Khoa Thủy sản, Truờng Đại học Cần Tho

*Nguòi chịu trách nhiệm về bài viết: Bùi Thị Bích Hằng (email: btbhang@ctu.edu.vn)

\section{Thông tin chung:}

Ngày nhận bài: $22 / 02 / 2021$

Ngày nhận bài sửa: 11/05/2021

Ngày duyệt đăng: 01/06/2021

Title:

Effect of dietary Premna serratifolia L. extract supplementation interval on immune response and disease resistance of striped catfish (Pangasianodon hypophthalmus)

\section{Tù khóa:}

E. ictaluri, hệ miễn dịch, kháng bệnh, Pangasianodon hypophthalmus, Premna serratifolia

\section{Keywords:}

Disease resistance, E. ictaluri, Pangasianodon hypophthalmus, Premna serratifolia, immune system

\begin{abstract}
The study was conducted to evaluate the effect of the interval of $2 \%$ Premna serratifolia extract on immune response and disease resistance of striped catfish (Pangasianodon hypophthalmus). The experiment was completely randomized design with 3 treatments including 2 supplemented treatments of 2\% Premna serratifolia leaf extract with different interval supplementation, 2 weeks/month (week $1^{\text {st }}, 2^{\text {nd }}$ and $5^{\text {th }}, 6^{\text {th }}$ ) and for 4 weeks (week $1^{\text {st }}$ to $4^{\text {th }}$ ), and a control treatment (without herbal extract) for 8 weeks, each treatment was replicated 4 times. Hematological and immunological parameters including blood cells count, lysozyme, complement activity and phagocytic activity were monitored at $2^{\text {nd }}, 4^{\text {th }}$ and $8^{\text {th }}$ week of the experiment. After 8 weeks of $P$. serratifolia extract supplementation, fish were challenged with Edwardsiella ictaluri pathogenic strain. Results showed that the immunological parameters supplemented treatments were higher than those of control. Treatment of $2 \%$. serratifolia extract supplementation with 2-week interval stimulated the innate immune system of fish. The accumulative mortality of fish in treatment of 2\% P. serratifolia extract supplementation with 2-week interval were also significantly lower than those in the control treatment. These results addressed that $P$. serratifolia extract supplementation with 2 weeks interval could enhance fish health and protect striped catfish from E. ictaluri infection.
\end{abstract}

\section{TÓM TẮT}

Nghiên cứu được thực hiện nhằm đánh giá ảnh hưởng của chu kỳ bổ sung $2 \%$ chất chiết lá cách (Premna serratifolia) vào thức ăn lên đáp ứng miễn dịch và khả năng kháng bệnh gan thận mủ của cá tra (Pangasianodon hypophthalmus). Thí nghiệm đuoọc bố trí hoàn toàn ngẫu nhiên trong 8 tuần với 3 nghiệm thức bao gồm hai nghiệm thức bổ sung $2 \%$ chất chiết lá cách với nhịp bổ sung 2 tuần/tháng (tuần 1, 2 vả 5,6 ); liên tục 4 tuần (tuần 1, 2, 3, 4) và nghiệm thức đối chứng (không bổ sung lá cách), mồi nghiệm thức lặp lại 4 lần. Các chì tiêu huyết học và miễn dịch bao gồm tế bào máu, hoạt tính lysozyme, hoạt tính bố thể và hoạt tính đại thưc bào đwợc theo dõi vào tuần thư 2,4 và 8 của thí nghiệm. Sau 8 tuần bổ sung lá cách, cá được cảm nhiếm với vi khuẩn E. ictaluri. Kết quả cho thấy cá ở các nghiệm thức bổ sung $2 \%$ chất chiết lá cách theo các chu kỳ khác nhau đều gia tăng đáp ứng miễn dịch so với nhóm đối chứng. Nghiệm thức bổ sung 2\% chất chiết lá theo nhịp cách khoảng 2 tuần làm gia tăng chỉ tiêu huyết hoc và hệ miễn dịch không đặc hiệu của cá. Tì lệ chết của cá ăn thức ăn bổ sung chiết lá cách theo nhịp 2 tuần/tháng cũng thấp hơn đối chứng. Kết quả thí nghiệm chỉ ra bổ sung $2 \%$ chất chiết lá cách theo nhịp 2 tuần/tháng có khả năng tăng cường sức khỏe của cá và bảo vệ cá kháng lại vi khuẩn E. ictaluri khi gây cảm nhiểm. 


\section{GIỚI THIỆ}

Thủy sản là một trong những ngành mũi nhọn đóng góp một phần quan trọng vào GDP của Việt Nam. Theo báo cáo của Tổng cục Thủy sản (2018), giá trị sản xuất thủy sản đạt khoảng 10 tỷ USD, trong đó xuất khẩu cá tra của Việt Nam đạt gần 2,26 tỷ USD. Tuy nhiên, phát triển nuôi cá tra với quy mô công nghiệp đang gặp nhiều trở ngại. Việc mở rộng diện tích, nâng cao sản lượng dẫn đến tình hình dịch bệnh phát triển càng nhiều. Đây cũng là một trong những nguyên nhân làm giảm năng suất cá tra.

Để hạn chế dịch bệnh trong thủy sản, nhiều chất chiết thảo dược ứng dụng trong phòng và trị bệnh động vật thủy sản cho thấy kết quả rất khả quan. Chiết xuất từ thảo dược đóng vai trò quan trọng trong việc kiểm soát dịch bệnh vì chứa những chất có hoạt tính chống oxy hóa, kháng khuẩn, kháng stress, đồng thời kích thích sự tăng trưởng, thèm ăn, tăng cường hệ miễn dịch và kích thích sinh sản (Chitmanat et al., 2003; Chakraborty \& Hancz, 2013). Một số nghiên cứu cho thấy nhiều loại thảo dược có khả năng kháng vi sinh vật tốt, là giải pháp sinh học thay thế thuốc và hóa chất trong nuôi thủy sản. Nghiên cứu bổ sung chất chiết gừng vào thức ăn làm tăng cường đáp ứng miễn dịch của cá hồi (Nya \&Austin, 2009) và cá chẽm (Talpur et al., 2013). Chiết xuất từ ồi (Psidium guajava) có khả năng kiểm soát và hạn chế được dịch bệnh do Aeromonas hydrophila gây ra trên cá nhờ tác dụng tăng hoạt tính miễn dịch (Rattanachaikunsopon et al., 2009). Thực nghiệm cho thấy sử dụng thảo dược và chất chiết thảo dược trong phòng trị bệnh cá đang là xu hướng có nhiều triển vọng phát triển trong tương lai.

Theo Đỗ Tất Lợi (2004), cây vọng cách mọc hoang khắp ở Việt Nam, Lào, Campuchia và ở Ấn Độ, Indonesia, Philippines, Úc. Thành phần hóa học ở vỏ thân có hai alkaloids là premnine và ganiarine, có tác dụng tăng cường thần kinh giao cảm, tăng huyết áp, tăng tiết nước bọt, nở đồng tử, tăng nhu động ruột, nở khí quản, ứng dụng lâm sàng của vị thuốc lá cách chữa kiết lỵ, chữa gan nhiễm mỡ, da vàng, kém ăn, đầy bụng, điều hòa kinh nguyệt, an thần. Nghiên cứu của Đái Thị Xuân Trang và ctv. (2018) cho thấy cây vọng cách là một dược liệu tiềm năng, chứa nhiều các hợp chất kháng oxi hóa và kháng khuẩn tự nhiên. Cao chiết lá vọng cách có hiệu quả kháng khuẩn cao với 6 chủng vi khuẩn: Escherichia coli, Samonella typhimurium, Listeria innocua, Staphylococcus aureus, Pseudomonas aeruginosa và Vibrio parahaemolyticus. Quách Thị Thanh Tâm (2019) đã xác định liều bổ sung $2 \%$ chất chiết lá cách vào thức ăn làm gia tăng một số chỉ tiêu huyết học và hoạt tính lysozyme của cá tra. Tuy nhiên, chưa có nghiên cứu nào tìm hiểu thời gian phù hợp bổ sung chất chiết lá cách vào thức ăn cá tra. Do vậy, nghiên cứu này được thực hiện nhằm tìm hiểu sự ảnh hưởng của chu kì bổ sung chất chiết lá cách (Premna serratifolia L.) lên các chỉ tiêu miễn dịch ở cá tra (Pangasianodon hypophthalmus), là cơ sở đề xuất phương pháp phòng và trị bệnh trên cá tra.

\section{VẠT LIỆU VÀ PHƯƠNG PHÁP NGHIỀ CÚU}

\subsection{Nguồn vật liệu}

Nguồn cá: Cá tra (Pangasianodon hypophthalmus) có khối lượng 15-20g/con được vận chuyển từ trại giống ở Cần Thơ về trại thực nghiệm Khoa Thủy sản và thuần dưỡng 2 tuần trước khi tiến hành thí nghiệm. Cá được trữ trong bể composite 2 $\mathrm{m}^{3}$ có sục khí liên tục, cho ăn bằng thức ăn công nghiệp theo nhu cầu của cá. Trước khi thực hành thí nghiệm, 10 cá được kiểm tra ngẫu nhiên về hình dạng bên ngoài (không dị tật, không sây sát, màu sắc tươi sáng), ký sinh trùng, vi khuẩn để đảm bảo cá thí nghiệm khỏe và không nhiễm bệnh.

Nguồn thảo dực: Chất chiết lá cách được cung cấp bởi Khoa Khoa học Tự nhiên, Trường Đại học Cần Thơ. Lá cách sau khi thu về loại bỏ phần sâu bệnh, rửa sạch và sấy khô ở nhiệt độ từ $40-45^{\circ} \mathrm{C}$. Mẫu sau khi khô được xay nhuyễn thành mẫu bột nguyên liệu. Bột nguyên liệu được cho vào trong túi vải và ngâm trong dung môi methanol. Mẫu được ngâm 5 lần, mỗi lần ngâm khoảng 24 giờ, dịch chiết từ các lần ngâm được gom lại, cô quay đuổi dung môi thu được cao tổng thực vật (Nguyễn Kim Phi Phụng, 2007).

Thức ăn thí nghiệm: Thức ăn sử dụng trong quá trình thí nghiệm là thức ăn viên dạng nổi $32 \%$ đạm, kích cỡ $2 \mathrm{~mm} /$ viên (Grosbest). Chất chiết lá cách được cân theo tỉ lệ của mỗi nghiệm thức, pha loãng với $10 \mathrm{~mL}$ DMSO và tiếp tục với $10 \mathrm{~mL}$ nước cất, phun và trộn đều cho chất chiết thấm vào thức ăn, để khô tự nhiên trong vòng 4 giờ. Sau đó áo ngoài viên thức ăn bằng $0,5 \%$ dầu mực, tiếp tục để khô tự nhiên trong 8 giờ ở nhiệt độ phòng. Thức ăn được đóng gói và trữ ở $4^{\circ} \mathrm{C}$ trong suốt thời gian thí nghiệm.

\subsection{Phương pháp bố trí thí nghiệm}

Thí nghiệm bổ sung chất chiết lá cách: thí nghiệm được bố trí hoàn toàn ngẫu nhiên với ba nghiệm thức bao gồm: Đối chứng (không bổ sung chất chiết lá cách - NT1); $2 \%$ (theo khối lượng khô) 
chất chiết lá cách với nhịp bổ sung 2 tuần/tháng (tuần $1,2,5$ và 6 - NT2); $2 \%$ chất chiết lá cách trong 4 tuần liên tục (tuần $1,2,3$ và 4 -NT3), mỗi nghiệm thức lặp lại 4 lần. Thí nghiệm được thực hiện trong 8 tuần. Cá được bố trí $40 \mathrm{con} / \mathrm{bể} 250 \mathrm{~L}$, các bể được sục khí liên tục và thay nước 2 ngày/lần (10-30\% nước trong bể). Cá được cho ăn 3 lần/ngày với khẩu phần $3 \%$ khối lượng thân. Tiến hành thu mẫu máu của 3 cá /bể vào tuần thứ 2,4 và 8 . Mẫu được trữ ở $-20^{\circ} \mathrm{C}$ cho đến khi phân tích các chỉ tiêu huyết học và miễn dịch. Ở tuần thứ 8 , cá được cân khối lượng để phân tích tăng trưởng và tiến hành cảm nhiễm với vi khuẩn $E$. ictaluri để đánh giá khả năng kháng bệnh với vi khuẩn của cá thí nghiệm.

Thí nghiệm cảm nhiễm: Vi khuẩn $E$. ictaluri từ bộ sưu tập vi khuẩn của Bộ môn Bệnh học Thủy sản được nuôi tăng sinh trong môi trường Nutrient Broth, ly tâm ở 4.000 vòng/phút trong 15 phút ở $4^{\circ} \mathrm{C}$. Mật độ vi khuẩn được xác định bằng máy so màu quang phổ ở bước sóng $610 \mathrm{~nm}$. Nguồn vi khuẩn này được sử dụng để cảm nhiễm cho cá trong thí nghiệm tiếp theo.

Sau 8 tuần bổ sung chất chiết lá cách theo các chu kỳ khác nhau, cá được cảm nhiễm với vi khuẩn E. ictaluri. Thí nghiệm được bố trí hoàn toàn ngẫu nhiên với 4 nghiệm thức bao gồm nghiệm thức Đối chứng; $2 \%$ chất chiết lá cách với nhịp bổ sung 2 tuần/tháng (tuần 1,2 và 5,6 ); $2 \%$ chất chiết lá cách với nhịp bổ sung 4 tuần liên tục (tuần $1,2,3$ và 4 ) được tiêm với vi khuẩn và 1 nghiệm thức đối chứng âm (cá nhóm đối chứng được tiêm $0,85 \% \mathrm{NaCl}$ ). Mỗi nghiệm thức lặp lại 3 lần, 10 cá/bể, sục khí liên tục và không thay nước cá. Trong thời gian cảm nhiễm cá được cho ăn bằng thức ăn công nghiệp theo nhu cầu. Thí nghiệm cảm nhiễm được thực hiện bằng phương pháp tiêm vi khuẩn với mật độ $10^{5}$ $\mathrm{CFU} / \mathrm{mL}$ tương ứng với giá trị LD50, liều lượng 0,1 $\mathrm{mL} / \mathrm{cá}$ (Hang et al., 2013). Theo dõi cá trong 2 tuần, ghi nhận những biểu hiện bệnh lý và số lượng cá chết. Mẫu thận trước của cá lờ đờ, sắp chết được thu và trữ trong ethanol để tái định danh vi khuẩn.

\subsection{Phương pháp phân tích}

\subsubsection{Chỉ tiêu huyết học}

Định lương hồng cầu: được thực hiện theo phương pháp của Natt and Herrick (1952), mật độ hồng cầu được xác định bằng buồng đếm Neubauer và tính theo công thức: $\mathrm{HC}=\mathrm{C} \times 10 \times 5 \times 200$ $\left(\mathrm{tb} / \mathrm{mm}^{3}\right)(\mathrm{C}$ : Tổng số hồng cầu trong 5 vùng đếm)

Định lượng tổng bạch cầu và tùng loại bạch cầu: được thực hiện theo phương pháp của Hrubec et al. (2000). Trải mẫu máu bằng cách nhỏ một giọt máu lên lame, sau đó dùng lame chạm vào giọt máu và đẩy lame ngược về phía trước. Mẫu máu sau khi khô được cố định trong methanol 1 phút. Để mẫu khô tự nhiên và nhuộm Wright \& Giemsa. Tổng số lượng bạch cầu được tính theo công thức: $\mathrm{TBC}$ $\left(\mathrm{tb} / \mathrm{mm}^{3}\right)=($ Số $\mathrm{BC}$ trong 1.500 tế bào $\times \mathrm{R}) / \mathrm{Số} \mathrm{HC}$ trong 1.500 tế bào (TBC: mật độ tổng bạch cầu, $\mathrm{BC}$ : bạch cầu, R: mật độ hồng cầu, $\mathrm{HC}$ : hồng cầu).

Định lượng từng loại bạch cầu trong tổng số 200 tế bào bạch cầu. Tính mật độ từng loại bạch cầu theo công thức: Mật độ loại bạch cầu $\left(\mathrm{tb} / \mathrm{mm}^{3}\right)=($ Số lượng mỗi loại bạch cầu $\times$ TBC)/200

\subsubsection{Hoạt tính lysozyme}

Hoạt tính lysozyme được phân tích theo phương pháp của Ellis (1990). Dựng đường chuẩn lysozyme với các nồng độ $0,2,4,8$ và $16 \mu \mathrm{g} / \mathrm{mL}$. Cho $10 \mu \mathrm{L}$ dung dịch từ các nồng độ pha loãng cho vào đĩa 96 giếng, tiếp theo cho $200 \mu \mathrm{L} /$ giếng dịch huyền phù Micrococcus luteus (Sigma). Đối với mẫu huyết thanh của cá, cho $10 \mu \mathrm{L}$ huyết thanh vào đĩa 96 giếng, thêm $200 \mu \mathrm{L} /$ giếng vi khuẩn $M$. luteus. Hỗn hợp được ủ ở nhiệt độ $27^{\circ} \mathrm{C}$ và đo ở bước sóng 495 $\mathrm{nm}$. Hoạt tính lysozyme được tính dựa vào đường chuẩn lysozyme.

\subsubsection{Hoat tính bổ thể}

Hoạt tính bổ thể được phân tích theo phương pháp của Sunyer and Tort (1995) dựa trên sự phân giải hồng cầu của bổ thể. Cho $10 \mu \mathrm{L}$ hồng cầu cừu trộn đều với huyết thanh cá với nhiều nồng độ khác nhau $(0,01 ; 0,005 ; 0,0025 ; 0,00125 ; 0,00062,0)$, ủ 100 phút ở nhiệt độ $28^{\circ} \mathrm{C}$. Tiếp tục ly tâm $2.000 \mathrm{~g}$ trong 10 phút ở nhiệt độ phòng. Đọc mẫu ở bước sóng $405 \mathrm{~nm}$, hoạt tính bổ thể được tính theo phương pháp Milla et al. (2010).

\subsubsection{Hoạt tính đại thực bào}

Xác định hoạt tính đại thực bào dựa theo phương pháp của Ispir and Yonar (2007), 0,1 ml máu được trộn với $0,1 \mathrm{ml}$ Saccharomyces cerevisiae $\left(10^{7} / \mathrm{ml}\right)$ trong ống eppendoft $1,5 \mathrm{ml}$. Hỗn hợp được ủ 30 phút ở nhiệt độ $28^{\circ} \mathrm{C}$. Trộn đều hỗn hợp và trải đều $20 \mu \mathrm{l}$ dung dịch trên lame kính. Để lame khô tự nhiên, cố định tế bào bằng dung dịch methanol trong 1 phút. Tiếp tục nhuộm với Giemsa trong 30 phút, rửa sạch bằng nước cất. Quan sát hoạt tính thực bào bằng kính hiển vi. Hoạt tính thực bào dựa trên tổng số tế bào thực bào trong 100 đại thực bào đếm được.

\subsection{Phương pháp xử lý số liệu}

Tất cả số liệu được xử lí bằng phần mềm Excel, xử lí thống kê bằng phương sai ANOVA một nhân tố và so sánh sự khác biệt có ý nghĩa thống kê bằng 
phép thử DUNCAN ở mức ý nghĩa $5 \%$ bằng phần mềm SPSS.

\section{KẾT QUẢ VÀ THẢO LUẬN}

\subsection{Kết quả thí nghiệm}

\subsubsection{Chi tiêu huyết học}

Mật độ tổng hồng cầu: Sau 2 tuần bổ sung chất chiết lá cách theo các chu kỳ khác nhau, cả 2 nghiệm thức đều cho kết quả mật độ hồng cầu dao động từ $2,74 \times 10^{6}$ đến $2,88 \times 10^{6}$ tế bào/ $\mathrm{mm}^{3}$, cao hơn có ý nghĩa thống kê so với nghiệm thức đối chứng $(2,49$ $\times 10^{6}$ tế bào/ $\left.\mathrm{mm}^{3}\right)(\mathrm{p}<0,05)$ (Hình 1$)$. Trong đó, nghiệm thức 3 đạt giá trị cao nhất $2,88 \times 10^{6}$ tế bào $/ \mathrm{mm}^{3}$. Sau 4 tuần thí nghiệm, mật độ hồng cầu của các nghiệm thức dao động từ 2,82 đến $3,1 \times 10^{6}$ tế bào/ $\mathrm{mm}^{3}$, đạt giá trị cao hơn có ý nghĩa thống kê so với nghiệm thức đối chứng $\left(2,54 \times 10^{6}\right.$ tế bào $\left./ \mathrm{mm}^{3}\right)(\mathrm{p}<0,05)$. Nghiệm thức 2 có mật độ hồng cầu cao nhất $\left(3,1 \times 10^{6}\right.$ tế bào $\left./ \mathrm{mm}^{3}\right)$ và khác biệt có ý nghĩa thống kê so với các nghiệm thức còn lại. Sau 8 tuần bổ sung chất chiết xuất thảo dược, mật độ hồng cầu của các nghiệm thức được bổ sung thảo dược dao động từ 2,91 đến $3,2 \times 10^{6}$ tế bào $/ \mathrm{mm}^{3}$ và khác biệt thống kê so với nghiệm thức đối chứng $\left(2,62 \times 10^{6}\right.$ tế bào/mm $\left.\mathrm{mm}^{3}\right)(\mathrm{p}<0,05)$. Nghiệm thức bổ sung chất chiết lá cách theo chu kỳ cách khoảng 2 tuần cho kết quả mật độ hồng cầu tăng cao hơn các nghiệm thức khác.

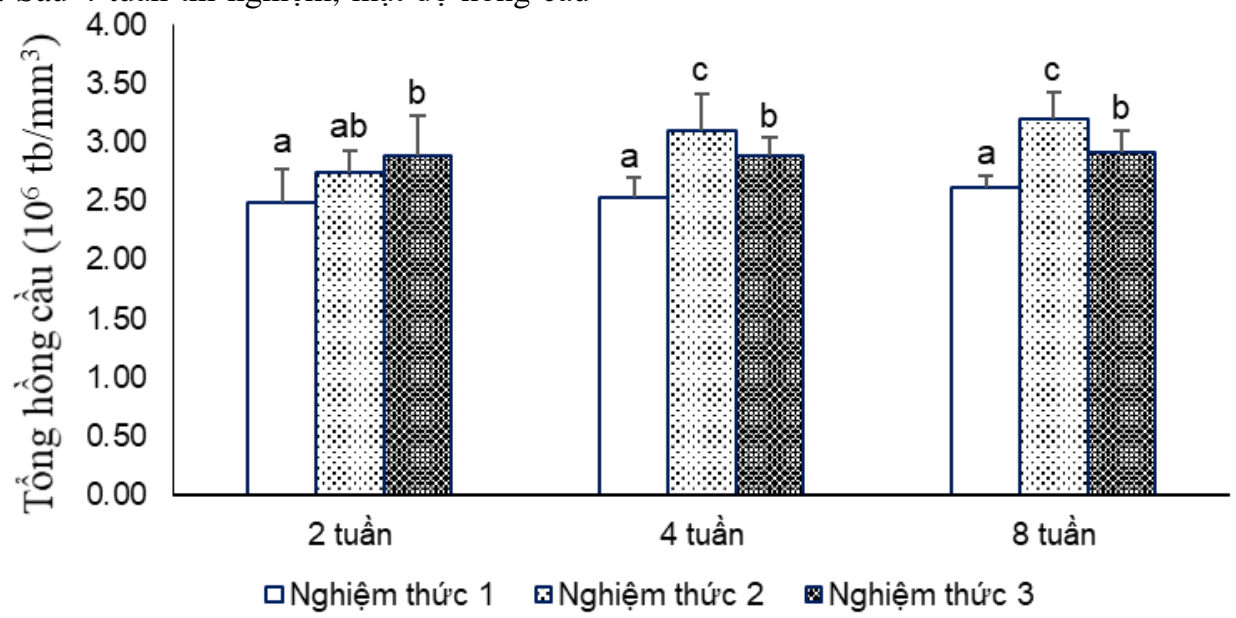

Hình 1. Ảnh hưởng của chất chiết lá cách lên mật độ hồng cầu cá tra

Ghi chú: Giá trị thể hiện là số trung bình \pm độ lệch chuẩn của 3 là̀n lặp lại thí nghiệm. Các giá trị trong cùng một thời điểm thu mẫu có các chũ cái giống nhau (a,b) thì khác biệt không có ý nghĩa thổng kê $(p<0,05)$.

Tổng bạch cầu: Kết quả sau 2 tuần thí nghiệm cho thấy cả 2 nghiệm thức bổ sung lá cách có mật độ tổng bạch cầu dao động từ $331,99 \times 10^{3}$ đến $340,32 \times 10^{3}$ tế bào $/ \mathrm{mm}^{3}$, cao hơn nghiệm thức đối chứng $\left(297,1 \times 10^{3}\right.$ tế bào/mm³ $)$, nhưng sự khác biệt này không có ý nghĩa thống kê (p>0,05). Nghiệm thức có mật độ bạch cầu đạt giá trị cao nhất là nghiệm thức $2\left(340,32 \times 10^{3}\right.$ tế bào $\left./ \mathrm{mm}^{3}\right)$ (hình 2$)$. Sau 4 tuần thí nghiệm, mật độ bạch cầu ở nghiệm thức 3 đạt giá trị cao nhất $\left(386,5 \times 10^{3}\right.$ tế bào $\left./ \mathrm{mm}^{3}\right)$ và khác biệt có ý nghĩa thống kê so với đối chứng $\left(306,92 \times 10^{3}\right.$ tế bào $\left./ \mathrm{mm}^{3}\right)(\mathrm{p}<0,05)$. Nghiệm thức 2 đạt giá trị cao hơn so với đối chứng nhưng sự khác biệt này không có ý nghĩa thống kê $(\mathrm{p}>0,05)$. Sau 8 tuần thí nghiệm, mật độ bạch cầu dao động từ 357,82 dến $424,75 \times 10^{3}$ tế bào $/ \mathrm{mm}^{3}$. Nghiệm thức 2 có mật độ bạch cầu đạt $424,75 \times 10^{3}$ tế bào $/ \mathrm{mm}^{3}$, cao hơn có ý nghĩa thống kê so với đối chứng $\left(330,85 \times 10^{3}\right.$ tế bào $\left./ \mathrm{mm}^{3}\right)(\mathrm{p}<0,05)$, nghiệm thức 3 có mật độ bạch cầu đạt giá trị $357,82 \times 10^{3}$ tế bào/ $/ \mathrm{mm}^{3}$, cao hơn mật độ bạch cầu của nghiệm thức đối chứng nhưng khác biệt không có ý nghĩa thống kê $(p>0,05)$. 


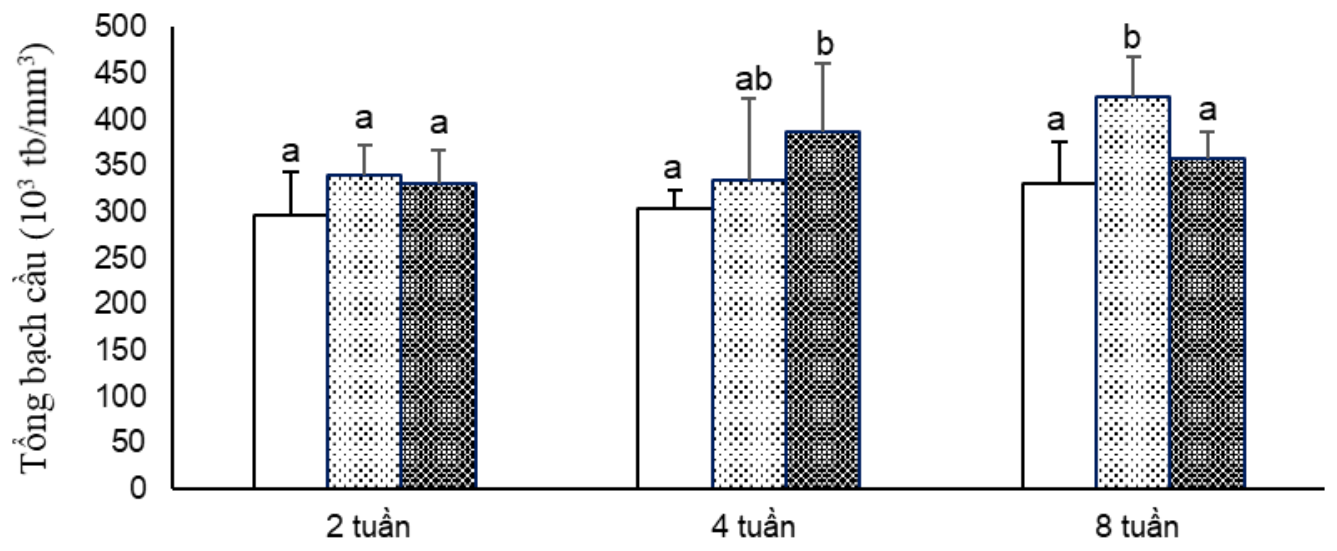

口Nghiệm thức 1 angiệm thức 2 aghiệm thức 3

Hình 2. Ảnh hưởng của chất chiết là cách lên mật độ bạch cầu cá tra

Ghi chú: Giá trị thể hiện là số trung bình \pm độ lệch chuẩn của 3 lần lặp lại thi nghiệm. Các giá trị trong cùng một thời điểm thu mẫu có các chũ cái giống nhau (a,b) thì khác biệt không có ý nghĩa thống kê $(p<0,05)$.

Bạch cầu đơn nhân: Sau 2 tuần thí nghiệm, mật độ tế bào bạch cầu đơn nhân của các nghiệm thức bổ sung chất chiết lá cách đều đạt giá trị tương đương nhau $\left(33,25 \times 10^{3}\right.$ và $34,72 \times 10^{3}$ tế bào/ $/ \mathrm{mm}^{3}$ ), cao hơn nhưng khác biệt có ý nghĩa thống kê so với đối chứng $(\mathrm{p}<0,05)$ (Bảng 1$)$. Sau 4 tuần thí nghiệm, các nghiệm thức được bổ sung chất chiết lá cách theo chu kỳ đều đạt giá trị cao hơn và khác biệt có ý nghĩa thống kê so với nghiệm thức đối chứng $(\mathrm{p}<0,05)$. Mật độ bạch cầu đơn nhân của cá ở nghiệm thức 3 đạt giá trị cao nhất $\left(37,93 \times 10^{3}\right.$ tế bào $/ \mathrm{mm}^{3}$ ). Sau 8 tuần thí nghiệm, mật độ bạch cầu đơn nhân của cá ở các nghiệm thức dao động từ 38,04 đến $45,01 \times 10^{3}$ tế bào $/ \mathrm{mm}^{3}$. Các nghiệm thức được bổ sung lá cách đều có mật độ bạch cầu đơn nhân cao hơn và khác biệt có ý nghĩa thống kê so với nghiệm thức đối chứng $(\mathrm{p}<0,05)$. Nghiệm thức 2 có mật độ bạch cầu đơn nhân đạt giá trị cao nhất, lần lượt là $\left(45,01 \times 10^{3}\right.$ tế bào $\left./ \mathrm{mm}^{3}\right)$, cao hơn có ý nghĩa so với các nghiệm thức còn lại $(\mathrm{p}<0,05)$.

Bảng 1. Mật độ bạch cầu đơn nhân, trung tính, lympho và tiểu cầu $\left(\times 10^{3}\right.$ tế bào/ $\left./ \mathrm{mm}^{3}\right)$ ở cá tra sau khi bổ sung chất chiết lá cách

\begin{tabular}{|c|c|c|c|}
\hline Nghiệm thức & 2 tuần & 4 tuần & 8 tuần \\
\hline \multicolumn{4}{|c|}{ Bạch cầu đơn nhân } \\
\hline NT 1 & $27,68 \pm 1,77^{\mathrm{a}}$ & $23,29 \pm 3,72^{\mathrm{a}}$ & $29,16 \pm 4,15^{\mathrm{a}}$ \\
\hline NT 2 & $34,72 \pm 4,36^{\mathrm{b}}$ & $30,37 \pm 5,06^{\mathrm{b}}$ & $45,01 \pm 4,15^{\mathrm{c}}$ \\
\hline NT 3 & $33,27 \pm 3,07^{\mathrm{b}}$ & $37,93 \pm 5,82^{\mathrm{c}}$ & $38,04 \pm 3,61^{\mathrm{b}}$ \\
\hline \multicolumn{4}{|c|}{ Bạch cầu trung tính } \\
\hline NT 1 & $29,72 \pm 2,76^{\mathrm{a}}$ & $29,06 \pm 2,65^{\mathrm{a}}$ & $34,77 \pm 2,91^{\mathrm{a}}$ \\
\hline NT 2 & $36,84 \pm 1,86^{\mathrm{b}}$ & $35,18 \pm 7,6^{\mathrm{bc}}$ & $45,73 \pm 4,28^{b}$ \\
\hline NT 3 & $34,48 \pm 4,1^{\mathrm{b}}$ & $39,45 \pm 8,02^{\mathrm{c}}$ & $37,82 \pm 4,01^{\mathrm{a}}$ \\
\hline \multicolumn{4}{|l|}{ Lympho } \\
\hline NT 1 & $208,17 \pm 34,09^{\mathrm{a}}$ & $222,49 \pm 16,13^{\mathrm{a}}$ & $228,48 \pm 32,4^{\mathrm{a}}$ \\
\hline NT 2 & $242,05 \pm 26,11^{\mathrm{a}}$ & $235,39 \pm 62,76^{\mathrm{ab}}$ & $289,91 \pm 31,52^{\mathrm{b}}$ \\
\hline NT 3 & $237,63 \pm 27,87^{\mathrm{a}}$ & $267,04 \pm 53,13^{\mathrm{b}}$ & $243,66 \pm 20,99^{\mathrm{ab}}$ \\
\hline \multicolumn{4}{|l|}{ Tiểu cầu } \\
\hline NT 1 & $28,91 \pm 11,52^{\mathrm{a}}$ & $28,26 \pm 5,29^{\mathrm{a}}$ & $37,8 \pm 8,28^{\mathrm{a}}$ \\
\hline NT 2 & $26,72 \pm 6,3^{\mathrm{a}}$ & $32,55 \pm 11,48^{\mathrm{ab}}$ & $43,91 \pm 5,44^{b}$ \\
\hline NT 3 & $25,1 \pm 6,64^{\mathrm{a}}$ & $39,49 \pm 7,08^{b}$ & $38,3 \pm 6,31^{\mathrm{ab}}$ \\
\hline
\end{tabular}

Ghi chú: Giá trị thể hiện là số trung bình \pm độ lệch chuẩn của 3 lần lặp lại thí nghiệm. Các giá trị trong cùng một thời điểm thu mẫu có các chũ cái giống nhau $(a, b)$ thì khác biệt không có ý nghĩa thổng kê $(p<0,05)$. 
Bạch cầu trung tính: Sau 2 tuần thí nghiệm, mật độ tế bào bạch cầu trung tính dao động từ $29,72 \times$ $10^{3}$ đến $36,84 \times 10^{3}$ tế bào $/ \mathrm{mm}^{3}$ (Bảng 1 ). Các nghiệm thức bổ sung lá cách đều có giá trị cao hơn và khác biệt có ý nghĩa thống kê so với nghiệm thức đối chứng $(\mathrm{p}<0,05)$. Nghiệm thức 2 có mật độ bạch cầu trung tính đạt giá trị cao nhất $\left(36,84 \times 10^{3}\right.$ tế bào $/ \mathrm{mm}^{3}$ ). Sau 4 tuần thí nghiệm, mật độ tế bào bạch cầu trung tính ở các nghiệm thức dao động từ 29,06 đến $39,45 \times 10^{3}$ tế bào $/ \mathrm{mm}^{3}$. Nghiệm thức 3 có mật độ bạch cầu trung tính đạt giá trị cao nhất $(39,45 \times$ $10^{3}$ tế bào $/ \mathrm{mm}^{3}$ ), khác biệt thống kê so với nghiệm thức đối chứng $(\mathrm{p}<0,05)$. Sau 8 tuần thí nghiệm, các nghiệm thức được bổ sung chất chiết lá cách đều có mật độ bạch cầu trung tính đạt giá trị cao hơn nghiệm thức đối chứng. Trong đó nghiệm thức 2 đạt giá trị cao nhất $\left(45,73 \times 10^{3}\right.$ tế bào $\left./ \mathrm{mm}^{3}\right)$, khác biệt thống kê so với đối chứng $(\mathrm{p}<0,05)$. Nghiệm thức còn lại không có sự khác biệt thống kê so với nghiệm thức đối chứng ( $\mathrm{p}>0,05)$.

Mật độ tế bào lympho: Sau 2 tuần bổ sung chất chiết lá cách, mật độ tế bào lympho của các nghiệm thức đạt giá trị $237,6 \times 10^{3}$ và $242,1 \times 10^{3}$ tế bào/ $\mathrm{mm}^{3}$ cao hơn nghiệm thức đối chứng $(208,17 \times$ $10^{3}$ tế bào $/ \mathrm{mm}^{3}$ ), tuy nhiên sự khác biệt này không có ý nghĩa thống kê $(p>0,05)$ (Bảng 1$)$. Sau 4 tuần thí nghiệm, mật độ lympho của cá ở nghiệm thức 3 đạt $267,04 \times 10^{3}$ tế bào $/ \mathrm{mm}^{3}$, khác biệt có ý nghĩa thống kê so với nghiệm thức đối chứng $(\mathrm{p}<0,05)$. Nghiệm thức 2 có mật độ lympho cao hơn đối chứng nhưng khác biệt không có ý nghĩa thống kê $(\mathrm{p}>0,05)$. Sau 8 tuần thí nghiệm, mật độ tế bào lympho của các nghiệm thức bổ sung lá cách có mật độ lympho $243,66 \times 10^{3}$ và $289,91 \times 10^{3}$ tế bào $/ \mathrm{mm}^{3}$, cao hơn đối chứng $\left(228,48 \times 10^{3}\right.$ tế bào $/ \mathrm{mm}^{3}$ ). Nghiệm thức 2 có mật độ lympho $\left(289,92 \times 10^{3}\right.$ tế bào $\left./ \mathrm{mm}^{3}\right)$ cao hơn có ý nghĩa thống kê so với đối chứng $(\mathrm{p}<0,05)$.

Tiểu cầu: Sau 2 tuần thí nghiệm, các nghiệm thức bổ sung chất chiết lá cách có mật độ tiểu cầu dao động trong khoảng $26,72 \times 10^{3}$ đến $27,19 \times 10^{3}$ tế bào $/ \mathrm{mm}^{3}$, khác biệt không có ý nghĩa thống kê so với nghiệm thức đối chứng ( $\mathrm{p}>0,05)$ (Bảng 1$)$. Sau 4 tuần thí nghiệm, mật độ tiểu cầu của cá ở các nghiệm thức bổ sung chất chiết lá cách dao động từ 32,55 đến $39,49 \times 10^{3}$ tế bào $/ \mathrm{mm}^{3}$, có giá trị cao hơn nghiệm thức đối chứng $\left(28,26 \times 10^{3}\right)$. Nghiệm thức 3 có mật độ tiểu cầu đạt giá trị cao nhất là $39,49 \mathrm{x}$ $10^{3}$ tế bào $/ \mathrm{mm}^{3}$, khác biệt thống kê so với nghiệm thức đối chứng $(\mathrm{p}<0,05)$. Sau 8 tuần, các nghiệm thức bổ sung chất chiết lá cách theo các chu kỳ khác nhau có mật độ tiểu cầu dao động từ 38,3 đến 43,9 x $10^{3}$ tế bào $/ \mathrm{mm}^{3}$, cao hơn nghiệm thức đối chứng. Nghiệm thức 2 đạt giá trị cao nhất $\left(43,9 \times 10^{3}\right.$ tế bào $/ \mathrm{mm}^{3}$ ) và khác biệt thống kê so với nghiệm thức đối chứng $(\mathrm{p}<0,05)$.

\subsubsection{Chỉ tiêu miễn dịch}

Hoạt tính lysozyme: Kết quả nghiên cứu cho thấy, sau 2 tuần bổ sung chất chiết lá cách theo các chu kì khác nhau, hoạt tính lysozyme trung bình của các nghiệm thức dao động từ 165,3 - 170,6 $\mu \mathrm{g} / \mathrm{mL}$ và đều tăng cao hơn có ý nghĩa thống kê so với nghiệm thức đối chứng 135,7 $\mu \mathrm{g} / \mathrm{mL}$ (p<0.05) (Hình 3). Sau 4 tuần thí nghiệm, hoạt tính lysozyme của cá ở các nghiệm thức đều tăng so với lần thu mẫu ở tuần thứ 2 và dao động từ $162,8-197,7 \mu \mathrm{g} / \mathrm{mL}$. Hoạt tính lysozyme của các nghiệm thức được bổ sung 2 \% lá cách theo các chu kỳ khác nhau đều tăng cao và khác biệt có ý nghĩa thống kê so với nghiệm thức đối chứng $(\mathrm{p}<0.05)$. Trong đó, nghiệm thức 3 đạt giá trị cao nhất $197,7 \mu \mathrm{g} / \mathrm{mL}$. Sau 8 tuần thí nghiệm, hoạt tính lysozyme ở các nghiệm thức dao động từ $164,7-207,4 \mu \mathrm{g} / \mathrm{mL}$. Trong đó, nghiệm thức bổ sung $2 \%$ lá cách theo chu kỳ cách khoảng 2 tuần cho kêt quả tăng cao nhất, khác biệt có ý nghĩa thống kê so với nghiệm thức đối chứng. Nghiệm thức bổ sung chất chiết lá cách theo chu kỳ 4 tuần liên tục cho hoạt tính lysozyme thấp và khác biệt không có ý nghĩa thống kê so với đối chứng $(\mathrm{p}<0.05)$. Kết quả này cho thấy bổ sung chất chiết lá cách theo chu kì 2 tuần kích hoạt hoạt tính lysozyme tốt nhất. 


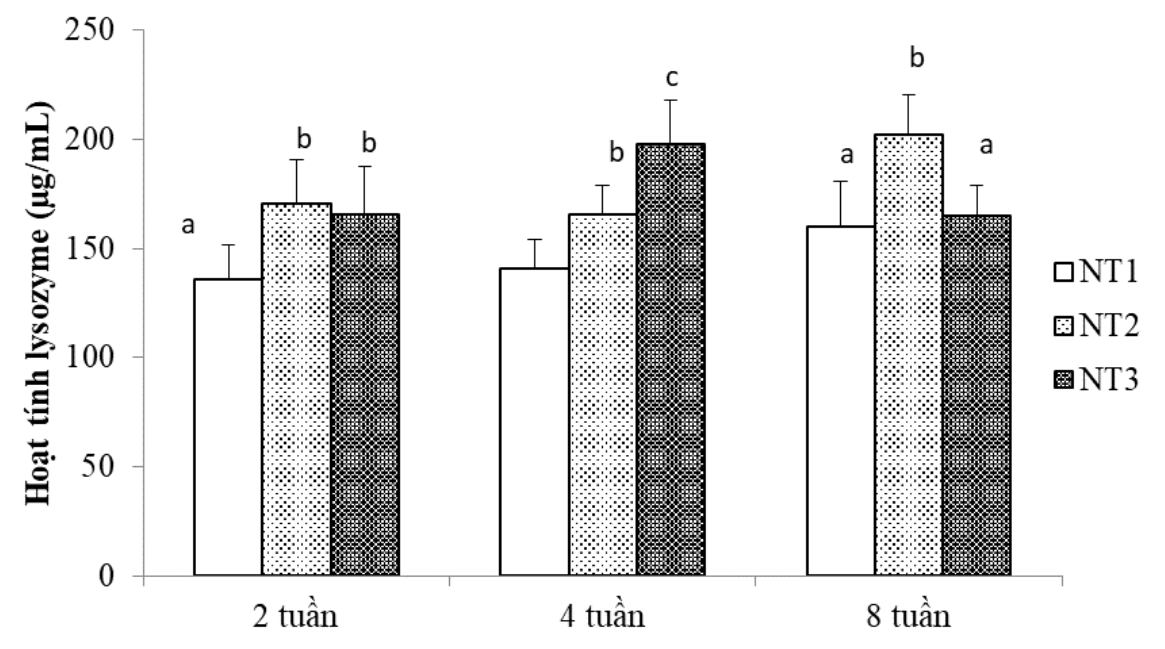

\section{Hình 3. Ảnh hưởng của chu kì bổ sung chất chiết lên hoạt tính lysozyme của cá tra}

Ghi chú: Giá trị thể hiện là số trung bình \pm độ lệch chuẩn của 3 lần lặp lại thí nghiệm. Các giá trị trong cùng một thời điểm thu mẫu có các chũ cái giống nhau $(a, b)$ thi khác biệt không có ý nghĩa thông kê $(p<0,05)$.

Hoạt tính bổ thể: Kết quả sau 2 tuần thí nghiệm cho thấy hoạt tính bổ thể của 2 nghiệm thức bổ sung chất chiết lá cách dao động từ 19,47 -20.83 U/mL, cao hơn nghiệm thức đối chứng $(15,6 \mathrm{U} / \mathrm{mL})$ có ý nghĩa thống kê $(\mathrm{p}<0,05)$ (hình 4). Trong đó, nghiệm thức 3 có hoạt tính bổ thể đạt giá trị cao nhất $(20,83$ $\mathrm{U} / \mathrm{mL}$ ). Sau 4 tuần thí nghiệm, hoạt tính bổ thể ở nghiệm thức 3 đạt giá trị cao nhất $(24,8 \mathrm{U} / \mathrm{mL})$ và khác biệt có ý nghĩa thống kê so với đối chứng $(15,6$ $\mathrm{U} / \mathrm{mL})(\mathrm{p}<0,05)$. Sau 8 tuần thí nghiệm, hoạt tính bổ thể của các nghiệm thức dao động từ $18,4-25,3$ $\mathrm{U} / \mathrm{mL}$. Nghiệm thức 2 có hoạt tính bổ thể là 25,35 $\mathrm{U} / \mathrm{mL}$, cao nhất và khác biệt có ý nghĩa thống kê so với đối chứng $(18,4 \mathrm{U} / \mathrm{mL})(\mathrm{p}<0,05)$.

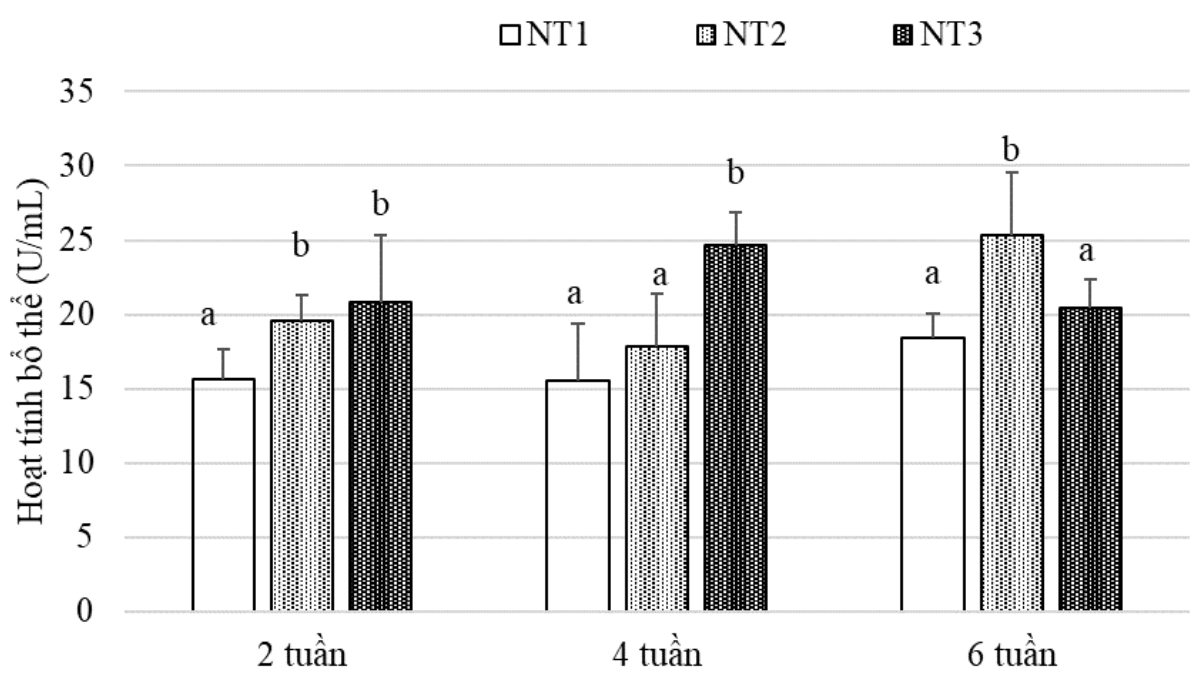

Hình 4. Ảnh hưởng của chu kì bổ sung chất chiết lên hoạt tính bổ thể của cá tra

Ghi chú: Giá trị thể hiện là số trung bình \pm độ lệch chuẩn của 3 lần lặp lại thí nghiệm. Các giá trị trong cùng một thời điểm thu mẫu có các chũ cái giống nhau (a,b) thì khác biệt không có ý nghĩa thổng kê $(p<0,05)$.

Hoạt tính đại thục bào: Sau 2 tuần thí nghiệm, hoạt tính đại thực bào dao động từ 45,7 - 46,1\% (Hình 5). Các nghiệm thức bổ sung chất chiết lá cách theo các chu kỳ khác nhau đều có hoạt tính đại thực bào cao hơn có ý nghĩa thống kê so với nghiệm thức đối chứng $(37,4 \%)(\mathrm{p}<0,05)$. Sau 4 tuần thí nghiệm, 
hoạt tính đại thực bào ở các nghiệm thức dao động từ 40,39 - 51,56\%. Nghiệm thức 3 có mật độ bạch cầu trung tính đạt giá trị cao nhất (51,6\%), khác biệt thống kê so với nghiệm thức đối chứng và NT2 $(\mathrm{p}<0,05)$. Sau 8 tuần thí nghiệm, các nghiệm thức được bổ sung chất chiết lá cách đều có họat tính đại thực bào $(46,39$ - 52,3 \%) đạt giá trị cao hơn nghiệm thức đối chứng $(41,67 \%)$. Trong đó nghiệm thức 2 đạt giá trị cao nhất (52,3\%), khác biệt có ý nghĩa thống kê so với các nghiệm thức còn lại $(\mathrm{p}<0,05)$.

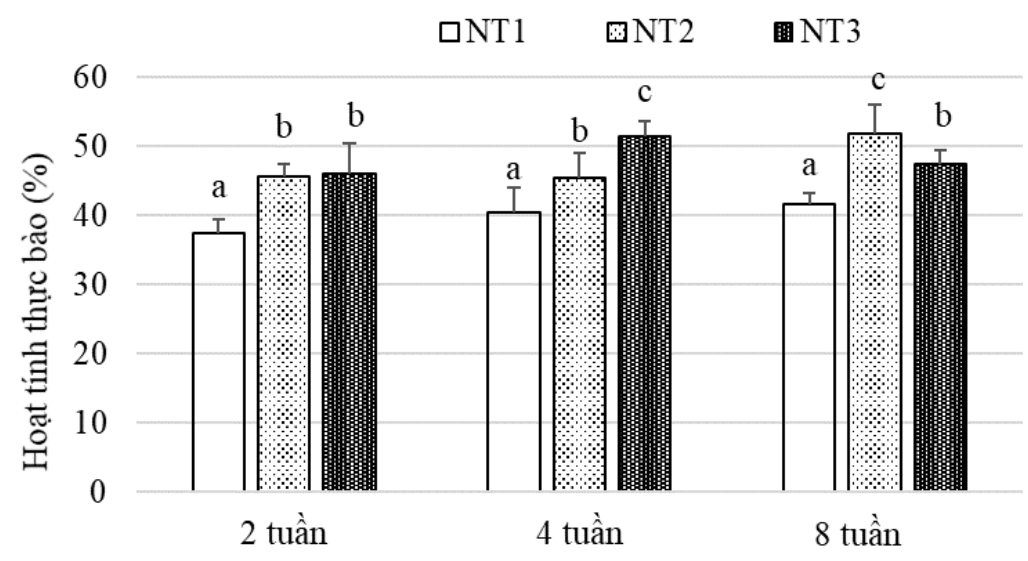

Hình 5. Ảnh hưởng của chu kì bổ sung chất chiết lên hoạt tính đại thực bào của cá tra

Ghi chú: Giá trị thể hiện là số trung bình \pm độ lệch chuẩn của 3 làn lặp lại thi nghiệm. Các giá trị trong cùng một thời điểm thu mẫu có các chũ cái giống nhau (a,b) thì khác biệt không có ý nghĩa thổng kê $(p<0,05)$.

\subsubsection{Anh hưởng của chu kỳ bổ sung chất chiết lá cách lên khả năng kháng vi khuẩn E. ictaluri}

Dấu hiệu bệnh lý: Cá được tiêm vi khuẩn bơi lờ đờ, vây có dấu hiệu tưa rách, xuất huyết nhẹ, bụng trương nhẹ. Bên trong xoang bụng có dịch, gan, thận và tỳ tạng xuất hiện nhiều đốm trắng nhỏ li ti (Hình 6). Cá được tiêm nước muối $(0,85 \% \mathrm{NaCl})$ khỏe mạnh và không có dấu hiệu bệnh lí, tỉ lệ sống đạt $100 \%$.

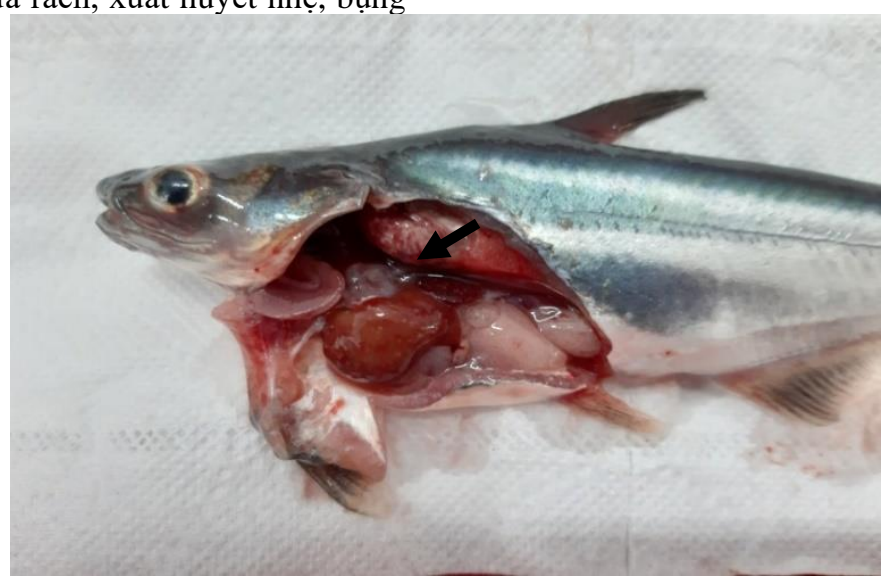

\section{Hình 6. Cá tra nhiễm vi khuẩn $E$. ictaluri (đốm trắng li ti xuất hiện trên gan thận cá)}

Tỉ lệ chết của cá cảm nhiễm: Kết quả cảm nhiễm cho thấy cá bắt đầu chết vào ngày thứ $3 \mathrm{sau}$ cảm nhiễm. Đến ngày thứ 6,7 cá chết giảm dần và ngừng chết vào ngày thứ 8 . Cá ở nghiệm thức tiêm nước muối sinh lý hoạt động bình thường, không biểu hiện bệnh và không có cá chết. Tỉ lệ chết ở các nghiệm thức NT2 là 28,6\%, NT3 là 33,3\%, thấp hơn có ý nghĩa thống kê so với nghiệm thức đối chứng $(66,7 \%)(\mathrm{p}<0,05)($ Hình 7). 


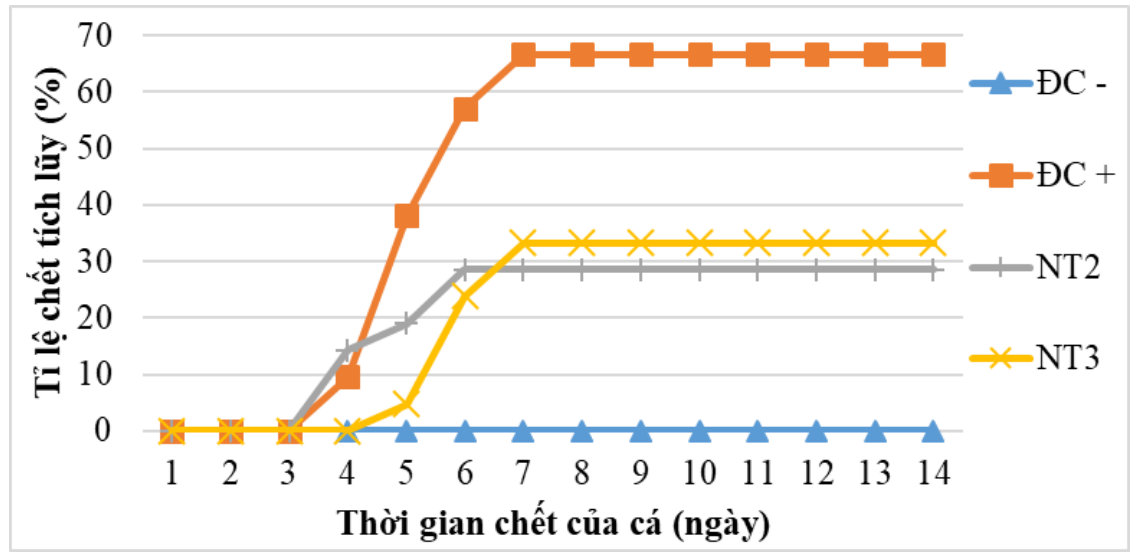

Hình 7. Tỉ lệ chết của cá cảm nhiễm sau 8 tuần thí nghiệm

Tái định danh vi khuẩn E. ictaluri: Kết quả tái định danh vi khuẩn bằng phương pháp $\mathrm{PCR}$ trên mẫu thận cá có biểu hiện bệnh cho thấy các mẫu đều thể hiện ở vạch đặc hiệu của E. ictaluri ở 407bp. Từ dấu hiệu bệnh lý và kết quả tái định danh cho thấy cá ở các nghiệm thức được tiêm $E$. ictaluri đều thể hiện dấu hiệu bệnh lý đặc trưng của bệnh gan thận mủ do E. ictaluri.

\section{THẢO LUẬN}

Hồng cầu có chức năng tham gia vào quá trình vận chuyển oxy đến các cơ quan và tế bào, tuy không tham gia trực tiếp vào quá trình đáp ứng miễn dịch nhưng cũng góp phần gián tiếp ảnh hưởng đến hệ miễn dịch của cá (Chinabut et al., 1991). Tương tự với kết quả của thí nghiệm, nghiên cứu của Glomski and Pica (2006) cũng ghi nhận sự biến động hồng cầu của cá mước ngọt trong khoảng 1 đến $3,5 \times 10^{6}$ tế bào $/ \mathrm{mm}^{3}$. Nghiên cứu của Mai Thanh Thanh và Bùi Thị Bích Hằng (2018) cho thấy mật độ hồng cầu của cá sau 14 ngày bổ sung tỏi vào thức ăn tăng cao hơn có ý nghĩa thống kê so với nghiệm thức đối chứng $(\mathrm{p}<0,05)$. Tương tự, kết quả nghiên cứu này cho thấy bổ sung chất chiết lá cách theo các chu kỳ khác nhau đều có thể kích hoạt mật độ bạch cầu trong máu cá tra. Điều này cũng tương đồng với các nghiên cứu trước đây, Binaii et al. (2014) bổ sung chất chiết từ cây tầm ma (Urtica dioica) vào thức ăn cá tầm (Huso huso) sau 8 tuần, mật độ tổng bạch cầu tăng cao nhất ở nghiệm thức $6 \%$, khác biệt so với đối chứng $(\mathrm{p}<0,05)$. Sử dụng $3.000 \mathrm{mg} / \mathrm{kg}$ chất chiết từ nước ép quả bứa bổ sung vào thức ăn cá tra, kết quả số lượng bạch cầu của cá tăng gấp 2 lần so với nghiệm thức đối chứng và các nghiệm thức khác (Prasad \& Priyanka, 2011). Một vài chiết xuất từ Ocimum sanctum, Emblica officinalis, Cynodon dactylon, và Adhatoda vasica cũng cho thấy có khả năng kích thích làm gia tăng tế bào bạch cầu và hoạt động thực bào ở cá vàng (Carassius auratis) (Selvaraj et al., 2005). Đặng Thị Hoàng Oanh và Trần Thị Yến Nhi (2011) bổ sung dịch chiết hoàng kỳ với liều lượng $0,5 \%$ vào thức ăn cá tra (20$30 \mathrm{~g} / \mathrm{con}$ ) trong 5 tuần cho thấy số lượng hồng cầu, tế bào lympho, bạch cầu đơn nhân, bạch cầu trung tính, tiểu cầu đều tăng so với cá ăn thức ăn không bổ sung dịch chiết hoàng kỳ. Thí nghiệm bổ sung chất chiết cây kế sữa vào thức ăn cá hồi cũng cho thấy số lượng tế bào lympho tăng lên tuy nhiên chỉ có nghiệm thức bồ sung $0,4 \mathrm{~g} / \mathrm{kg}$ tăng có ý nghĩa so với nghiệm thức đối chứng (Ahmadi et al., 2012).

Lysozyme còn được gọi là muramidase, là một loại chất diệt khuẩn có khả năng thủy phân $\beta$ $[1,4]$ mối liên hệ giữa axit $\mathrm{N}$ - acetylmuramic và $\mathrm{N}$ acetylgucosamine trong thành tế bào vi khuẩn. Do đó, lysozyme có thể tiêu diệt vi khuẩn Gram dương và một số vi khuẩn Gram âm, vì thế hoạt động của lysozyme càng cao thì khả năng kháng bệnh càng cao (Đỗ Ngọc Liên, 2004). Ngoài ra lysozyme còn có thể tương tác trực tiếp với bạch cầu và đại thực bào, kích thích và thúc đẩy sự thực bào (Saurabn \& Sahoo, 2008). Trong thí nghiệm này, bổ sung chất chiết lá cách theo các chu kỳ khác nhau đều kích hoạt gia tăng hoạt tính lysozyme trên cá tra. Kết quả này cũng phù hợp với nghiên cứu của Christybapita et al. (2007) khi bổ sung chất chiết cỏ mực vào thức ăn cá rô phi trong 3 tuần. Kết quả cho thấy hoạt tính lysozyme tăng cao chỉ sau 1 tuần thí nghiệm. Một thí nghiệm khác, trên cá chép (Cyprinus carpio) khi cho ăn chiết xuất sầu đâu $(0,25 ; 0,5$ và $0,75 \mathrm{~g} / \mathrm{kg}$ thức ăn) trong 30 ngày, kết quả ghi nhận cá ở nghiệm thức bổ sung chiết xuất sầu đâu $(0,25 \mathrm{~g} / \mathrm{kg}$ thức ăn) có hoạt tính lysozyme cao nhất (Valsa \& Balasubramanian, 2014). Kết quả của Gobi et al. (2016) cho thấy bổ sung chất chiết ổi vào thức ăn trong 30 ngày cũng làm tăng hoạt tính lysozyme trên 
cá rô phi đen. Nghiên cứu này cho kết quả tương tự, khi hoạt tính bổ thể của cá được bổ sung chất chiết lá cách tăng cao hơn so với nghiệm thức đối chứng. Bổ sung chất chiết theo chu kỳ 2 tuần/tháng cho thấy hoạt tính bổ thể tăng cao hơn so với bổ sung chất chiết 4 tuần liên tục. Hệ thống bổ thể là một trong những thành phần đóng vai trò chủ yếu trong phản ứng miễn dịch không đặc hiệu của động vật nói chung và cá nói riêng (Magnadorttir, 2006). Một vài nghiên cứu ảnh hưởng của chất điều biến miễn dịch lên hoạt tính bổ thể của cá cũng được chứng minh, Gobi et al. (2016) ghi nhận bổ sung chất chiết ổi vào thức ăn cá rô phi làm cá tăng trưởng nhanh, gia tăng hoạt tính bổ thể và tăng tính đề kháng với vi khuẩn gây bệnh Aeromonas hydrophila. Tuy nhiên, ở thí nghiệm đánh giá ảnh hưởng của chất chiết ổi lên đáp ứng miễn dịch của tế bào bạch cầu cá tra lại cho thấy hoạt động bổ thể gia tăng nhưng khác biệt không có ý nghĩa so với đối chứng (Trương Quỳnh Như và ctv., 2017). Ngoài ra, kết quả nghiên cứu còn ghi nhận hoạt tính thực bào ở cá tra ăn thức ăn được bổ sung chất chiết lá cách tăng cao hơn nhóm cá đối chứng. MacArthur and Fletcher (1985) cũng đã mô tả tế bào đại thực bào là thành phần tế bào quan trọng nhất và hoạt động thực bào là một trong những hoạt động đáp ứng miễn dịch quan trọng của động vật, quá trình thực bào diễn ra nhằm tiêu diệt các kháng nguyên, mầm bệnh hay những vật lạ xâm nhập vào cơ thể của động vật, giúp con vật đề kháng với một số tác nhân gây bệnh (Magnadorttir, 2006). Tế bào chính tham gia vào quá trình thực bào ở cá là tế bào trung tính và đại thực bào. Shahi et al. (2014) ghi nhận sự gia tăng hoạt động thực bào của các tế bào bạch cầu trên cá chép nhiễm vi khuẩn Aeromonas allosaccharophila.

Sau khi cảm nhiễm cá thí nghiệm với vi khuẩn $E$. ictaluri, dấu hiệu bệnh lý của cá tra được cảm nhiễm có biểu hiện tương tự dấu hiệu bệnh lý gan thận mủ trên cá tra được mô tả bởi Từ Thanh Dung và ctv. (2004). Nghiên cứu này cho thấy bổ sung $2 \%$ chất chiết lá cách theo chu kỳ 2 tuần/tháng cho tỉ lệ cá chết thấp nhất. Điều này hoàn toàn phù hợp với việc gia tăng chỉ số huyết học và miễn dịch của cá ở nghiệm thức bổ sung chất chiết lá cách. Trong đó, hoạt tính lysozyme, bổ thể và đại thực bào của cá được kích hoạt cao nhất ở nghiệm thức bổ sung theo chu kỳ 2 tuần/tháng so với việc bổ sung liên tục 4 tuần. Nghiên cứu của Quách Thị Thanh Tâm (2019) cũng ghi nhận bổ sung $2 \%$ chất chiết lá cách làm giảm tî̉ lệ chết của cá khi cảm nhiễm $E$. ictaluri. Tương tự, nghiên cứu của Nya and Austin (2009) về khả năng đáp ứng miễn dịch của cá hồi vân sau khi cho ăn thức ăn bổ sung Allicin trong 14 ngày đã ghi nhận cá được bổ sung allicin có tỉ lệ sống cao nhất là $88 \%$ so với $16 \%$ ở cá đối chứng sau khi cảm nhiễm với vi khuẩn Aeromonas hydrophila. Cá rô phi được cho ăn thức ăn bổ sung tỏi (Allium sativum) và Echnicacea purpurea có tî̉ lệ sống và sức đề kháng cao với mầm bệnh $A$. hydrophila (Aly \& Mohamed, 2010). Một nghiên cứu khác bổ sung tổ hợp các chất chiết xuất thực vật (nhóm 1: gồm hỗn hợp tỏi+gừng, nhóm 2: gồm hồn hợp Oregano+ Echinacea) vào thức ăn cá chép (Cyprinus carpio) trong 13 tuần, cho thấy tỉ lệ sống, tốc độ tăng trưởng và khả năng kháng vi khuẩn $A$. hydrophila ở cá được bổ sung chiết xuất thực vật tăng cao so với nhóm cá đối chứng (Gabor et al., 2012).

\section{KẾT LUẬN}

Cá tra giống ăn thức ăn có bổ sung chất chiết lá cách theo các chu kỳ khác nhau cho thấy có sự gia tăng các chỉ tiêu huyết học và miễn dịch bao gồm hoạt tính lysozyme, hoạt tính bổ thể và hoạt tính đại thực bào so với nhóm đối chứng. Sau 8 tuần thí nghiệm, nghiệm thức bổ sung $2 \%$ lá cách theo chu kỳ cách khoảng 2 tuần cho kết quả cá đáp ứng miễn dịch tốt nhất so với chu kỳ bổ sung 4 tuần liên tục và đối chứng. Ngoài ra, bổ sung $2 \%$ lá cách theo chu kỳ 2 tuần/tháng còn cho thấy khả năng đề kháng của cá đối với vi khuẩn Ewarsiella ictaluri tốt nhất

Đề xuất bổ sung $2 \%$ chất chiết lá cách vào thức ăn cá tra theo chu kỳ 2 tuần/tháng cần được nghiên cứu ứng dụng thực tế trong mô hình nuôi cá tra thương phẩm nhằm đánh giá hiệu quả tác động của chất chiết lá cách lên tăng trưởng, sức khỏe cũng như khả năng đề kháng bệnh của cá tra trong điều kiện ao nuôi thực tế.

\section{LỜI CẢM TẠ}

Nghiên cứu này được tài trợ bởi Dự án Nâng cấp Trường Đại học Cần Thơ VN14-P6 bằng nguồn vốn vay ODA từ Chính phủ Nhật Bản.

\section{TÀI LIẸU THAM KHẢO}

Ahmadi, K., Banaee, M., Vosoghei, A.R., Mirvaghefei, A.R., Ataeimehr, B. (2012).

Evaluation of the immunomodulatory effects of silymarin extract (Silybum marianum) on some immune parameters of rainbow trout, Oncorhynchus mykiss (Actinopterygii: Salmoniformes: Salmonidae). Acta Ichthyologica Et Piscatoria, 42(2), 113-120.

Aly, S.M., Mohamed, M.F. (2010). Echinacea purpurea and Allium sativum as immunostimulants in fish culture using Nile tilapia (Oreochromis niloticus). Journal of 
Animal Physiology and Animal Nutrion, 94(5), 31-39.

Binaii, M., Ghiasi, M., Farabi, S.M.V., Ourgholam, R., Fazli, H., Safari, R., Alavi, S.E., Taghavi, M.J., Bankehsaz, Z. (2014). Biochemical and hemato-immunological parameters in juvenile beluga (Huso huso) following the diet supplemented with nettle (Urtica dioica). Fish and Shellfish Immunology, 36, 46-51.

Chakraborty, S.B. \& Hancz, C. (2013). Application of phytochemicals as immunostimulant, antipathogenic and antistress agents in finfish culture. Reviews in Aquaculture, 3, 103-119.

Chinabut, S., Kisawat, P. and Limsuwan, C. (1991). Histology of the walking catfish, Clarias batrachus. International Development Research Center.

Chitmanat C., Tongdonmuan K., Khanom P., Pachontis P., Nunsong W. (2003). Antiparasitic, antibacterial, and antifungal activities derived from a Terminalia catappa solution against some tilapia (Oreochromis niloticus) pathogens. III WOCMAP Congress on Medicinal and Aromatic Plants-Volume 4: Targeted Screening of Medicinal and Aromatic Plants, Economics. Acta Horticulturae. 678.

10.17660/ActaHortic.2005.678.25.

Christybapita, D., Divyagnaneswari, M. and Dinakaran M.R. (2007). Oral administration of Eclipta alba leaf aqueour extract enhances the non-specific immune responses and disease resistance of Oreochromis mossambicus. Fish and Shellfish Immunology, 23(4), 840-852.

Đái Thị Xuân Trang, Trần Chí Linh, Nguyễn Thanh Nhị, Phan Kim Định, Trần Thanh Mến và Nguyễn Trọng Tuân. (2018). Khảo sát hoạt tính sinh học của cao chiếc lá cây vọng cách (Premna serratifolia (L.)). Tạp chi Khoa họ Truòng Đại hoc Cần Tho. 54(9A), 46-52.

Đặng Thị Hoàng Oanh và Trần Thị Yến Nhi. (2011). Ảnh hưởng của chiết xuất từ cây hoàng kỳ (Astragalus radix) lên một số chỉ tiêu miễn dịch không đặc hiệu của cá tra (Pagasianodon hypophthalmus). Kỷ yếu Hội nghị khoa hoc thủy sản lần 4, Truò̀ng Đại học Cần Tho, 278-288.

Đỗ Tất Lợi. (2004). Những cây thuốc và vị thuốc Việt Nam. Nhà xuất bản Y Học.

Ellis, A. E. (1990). Lysozyme Assays. In Stolen, JS., Fletcher, TC., Anderson, D. P., Roberson, BS., Van Muiswinkel, WB. (Eds.), Techniques in Fish Immunology, Vol. 1 (pp. 101-103). Fair Haven (USA): SPS Publications.

Gabor, E.F., Aurel, S., Bentea, M., Calina, C., Anca, B. (2012). The effect of phytoadditive combinations on growth and consumption indices and resistance to Aeromonas hydrophila in common carp (Cyprinus carpio) juveniles.
Iranian Journal of Aquatic Animal Health, 2(1), 24-36.

Glomski, C.A. and Pica, A. (2006). Erythrocyte of the poikilothrems: A phylogensis odyssey. Foxwell \& Davies (UK) Ltd.

Gobi, N., Ramya, C., Vaseeharan, B., et al. (2016). Oreochromis mossambicus diet supplementation with Psidium guajava leaf extracts enhance growth, immune, antioxidant response and resistance to Aeromonas hydrophila. Fish and Shellfish Immunology, 58, 572-583.

Hang B.T.B., Milla S., Gillardin V., Phuong N.T., Kestemont P. (2013). In vivo effects of Escherichia coli lipopolysaccharide on regulation of immune response and protein expression in striped catfish (Pangasianodon hypophthalmus). Fish and Shellfish Immunology, 34(1), 339-347.

Hrubec, T.C., J. L. Cardinale, S., and Smith, A. (2000). Hematology and plasma chemistry reference intervals for cultured Tilapia (Oreochromis hybrid). Veterinary Clinical Pathology, 29,7-12.

Ispir U., Yonar, M.E. (2007). Effects of Levamisole on Phagocytic Activity of Rainbow Trout (Oncorhynchus mykiss W.). Acta Veterinaria Brno, 76, 493-497.

MacArthur, J.I., Fletcher, T.C. (1985). Phagocytosis in fish. In: Manning MJ, Tatner MF (eds) Fish immunology. Academic Press, New York, pp 29-46.

Magnadorttir, B. (2006). Innate immunity of fish overview. Fish and Shellfish Immunology, 20, 137-151.

Mai Thanh Thanh và Bùi Thị Bích Hằng. (2018). Ảnh hưởng của việc bổ sung tỏi (Allium sativum) vào thức ăn lên một số chỉ tiêu miễn dịch và khả năng kháng khuẩn của cá điêu hồng. Tạp chí khoa hoc Truờng Đại hoc Cần Tho; 54(2), 168-176.

Milla, S., Mathieu, C., Wang, N., et al. (2010). Spleen immune status is affected after acute handling stress but not regulated by cortisol in Eurasian perch, Perca fluviatilis. Fish and Shellfish Immunology, 28, 931- 941.

Natt, M. P., Herrick C. A. (1952). A new blood diluent for counting erythrocytes and leukocytes of the chicken. Poultry Science, 31, 753-738.

Nya and Austin. (2009). Use of garlic, Allium sativum, to control Aeromonas hydrophila infection in rainbow trout, Oncorhynchus mykiss (Walbaum). Journal of Fish Diseases, 32, 963-970.

Nguyễn Kim Phi Phụng. (2007). Phuoong pháp cô lập hợp chất hưu co. Nhà xuất bản Đại học Quốc gia Tp. Hồ Chí Minh

Prasad, G., and Priyanka, G. L. (2011). Effect of fruit rind extract of Garcinia gummi-gutta on haematology and plasma biochemistry of catfish 
Pangasianodon hypophthalmus. Asian Journal Biochemistry, 6, 240-251.

Quách Thị Thanh Tâm. (2019). Tìm hiểu tác động của chất chiết thảo dược lên một số chỉ tiêu miễn dịch và khả năng kháng vi khuẩn Edwardsiella ictaluri trên cá tra. Luận văn cao hoc, Khoa Thủy sản, Đại hoc Cần Tho:

Rattanachaikunsopon, P., and Phumkhachorn, P. (2009). Potential of cinnamon (Cinnamomum verum) oil to control Streptococcus iniae infection in tilapia (Oreochromis niloticus). Fisheries Science, 76, 287-293.

Selvaraj, V., Sampath, K., Sekar, V. (2005). Administration of yeastglucan enhances survival and some non-specific and specificimmune parameters in carp (Cyprinus carpio) infected with Aeromonas hydrophila. Fish and Shellfish Immunology, 19, 293-306.

Sunyer, J.O. and Tort, L. (1995). Natural haemolytic and bactericidal activities of sea bream Sparus aurata serum are effected by the alternative complement pathway. Veterinary Immunology and Immunopathology, 45, 333-45.
Talpur, A.D., Ikhwanuddin, M. and Bolong, A.A. (2013). Nutritional effects of ginger (Zingiber officinale Roscoe) on immune response of Asian sea bass, Lates calcarifer (Bloch) and disease resistance against Vibrio harveyi. Aquaculture, 400, 46-52.

Từ Thanh Dung, Mags, Crumlish, Nguyễn thị Nhu Ngọc, Nguyễn Quốc Thịnh và Đặng Thụy Mai Thy. (2004). Xác định vi khuẩn gây bệnh trắng gan trên cá tra (Pangasius hypophthalmus). Tạp chi khoa học Truòng Đại học Cần Tho, số đặc biệt (chuyên ngành thủy sản), 137-142.

Trương Quỳnh Như, Nguyễn Thanh Phương và Bùi Thị Bích Hằng. (2018). Ảnh hưởng của chiết xuất ổi (Psidium guajava) và diệp hạ châu (Phylanthus amarus) lên đáp ứng miễn dịch của tế bào bạch cầu cá tra (Pangasianodon hypophthalmus). Tạp chi Khoa hoc Truòng Đại hoc Cần Tho, 54(2), 135-142.

Valsa, A.J. and Balasubramanian, V. (2014). A study on the immunoprotective effect of the medicinal plant Aloe Vera on the common carp Cyprinus carpio (L). Research of Journal Animal Veterinary Fisheries Science, 2(5), 1-5. 